\title{
KRONIKA
}

\section{MIĘDZYNARODOWE SYMPOZJUM „,OD NEOLITYZACJI DO POCZĄTKÓW EPOKI BRĄZU. PRZEMIANY KULTUROWE W MIĘDZYRZECZU ODRY I DNIEPRU MIĘDZY VI I II TYS. BC", BRZEŚĆ, REPUBLIKA BIALORUŚ, 28-31 MAJA 2000 R.}

W dniach od 28 do 31 maja 2000 roku w Brześciu (Białoruś) odbyło się międzynarodowe sympozjum archeologiczne „Od neolityzacji do początków epoki brązu. Przemiany kulturowe w międzyrzeczu Odry i Dniepru między VI i II tys. ВC' („Ад неалітызацыі да пачатку эпохі бронзы. Культурныя змены ў міжрэччы Одры і Дняпра паміж VI і II тыс. да н.э.”). Jego głównymi organizatorami były: Instytut Historii Narodowej Akademii Nauk Republiki Białoruś w Mińsku oraz Instytut Prahistorii Uniwersytetu im. Adama Mickiewicza w Poznaniu. W organizacji brały udział także: Wydziały Kultury i Edukacji Komitetu Wykonawczego Obwodu Brzeskiego, Państwowy Uniwersytet Pedagogiczny im. Aleksandra Puszkina w Brześciu, Instytut Wschodni Uniwersytetu im. Adama Mickiewicza w Poznaniu, Muzeum Krajoznawcze w Brześciu oraz Fundacja Uniwersytetu im. Adama Mickiewicza w Poznaniu.

W Komitecie Honorowym sympozjum zasiedli: Wasil B. Dałgaloj, przewodniczący Komitetu Wykonawczego Obwodu Brzeskiego, Tomasz Klimański, konsul generalny Rzeczypospolitej Polskiej w Brześciu, Rektor Uniwersytetu im. Adama Mickiewicza w Poznaniu - prof. dr hab. Stefan Jurga, Rektor Brzeskiego Państwowego Uniwersytetu Pedagogicznego im. Aleksandra S. Puszkina - prof. dr Wladimir A. Pleciuchow, członek rzeczywisty Narodowej Akademii Nauk Białorusi prof. dr hab. Michaił P. Kasciuk - dyrektor Instytutu Historii Narodowej Akademii Nauk Białorusi, prof. dr hab. Tomasz Jasiński - dziekan Wydziału Historycznego UAM, prof. dr hab. Hanna Kóčka-Krenz - dyrektor Instytutu Prahistorii UAM, prof. dr hab. Grzegorz Kotlarski - dyrektor Instytutu Wschodniego UAM oraz mgr inż. Tadeusz Kosicki - dyrektor Fundacji Uniwersytetu im. Adama Mickiewicza w Poznaniu. W skład Komitetu Organizacyjnego weszli: prof. dr hab. Elena Kaleczyc, prof. dr hab. Aleksander Kośko (jako współprzewodniczący) oraz dr hab. Michał Czarniauski, dr Janusz Czebreszuk, mgr Bartosz Józwiak, mgr Władimir Lakize, dr E. Laszkiewicz, dr Przemysław Makarowicz i dr Marzena Szmyt.

Przedmiotem zainteresowania uczestników sympozjum brzeskiego były obszary niżowe Europy leżące w międzyrzeczu Odry i Dniepru. Pod względem warunków naturalnych tworzą one jednolitą całość otwartą na zachód i wschód, natomiast od północy i południa ograniczona, odpowiednio: Bałtykiem oraz Karpatami i Sudetami. Teren ten prawie zawsze był swoistą mozaiką kulturową. W różnych okresach pradziejów na interesującym nas obszarze 
zachodziły złożone procesy przemian kulturowych, w których obok miejscowych czynników niżowych brały udział również tradycje pochodzenia zachodniego (z Jutlandii i obszarów dorzecza Renu i Łaby), południowego (z Kotliny Czeskiej i Kotliny Karpackiej), południowo-wschodniego (ze stepów nadczarnomorskich) oraz północno-wschodniego (ze strefy tajgi euroazjatyckiej).

W dotychczasowych badaniach nad prahistorią międzyrzecza Odry i Dniepru (czy szerzej - obszaru międzymorza bałtycko-czarnomorskiego) większy nacisk kładziono na wyszukiwanie różnic kulturowych pomiędzy poszczególnymi regionami składającymi się na wspomnianą część Europy. Ideą przewodnią sympozjum była próba zaakcentowania więzi interkulturowych czytelnych w tej strefie już w pradziejach. Szczególnie intensywna wymiana wzorów kulturowych, wyrobów, surowców i - last but not least - ludzi miała miejsce w okresie od początków procesu neolityzacji po etap kształtowania się najstarszych społeczeństw epoki metalu. Dzięki nim na szerokiej rubieży styku Wschodu i Zachodu powstały społeczeństwa, które można nazwać „wspólnotami pogranicza”.

W sympozjum wzięło udział ponad pięćdziesięciu archeologów z Białorusi, Polski, Rosji i Ukrainy. Prezentowali oni swoje referaty i komunikaty w jezzykach narodowych podczas czterech sesji, poruszających zagadnienia: procesów neolityzacji w międzyrzeczu Odry i Dniepru, charakteru i znaczenia kulturowego cech ,wschodnich" w dorzeczu Odry i Wisły w epoce neolitu, charakteru i znaczenia kulturowego cech ,,zachodnich" na wschód od dorzecza Wisły w epoce neolitu oraz kryteriów wydzielania, kierunków rozprzestrzeniania się i charakteru kulturowego początków epoki brązu w międzyrzeczu Odry i Dniepru. Współprzewodniczącymi sesji zawsze były dwie osoby: jedna z Polski, druga z Białorusi, Ukrainy bądź Rosji.

W sesji pierwszej (,Procesy neolityzacji w dorzeczu Odry i Dniepru”) swoje referaty wygłosili: L.L. Zalizniak, L. Czerniak i J. Kabaciński, A.G. Kaleczyc, W. Obuchowski, W.F. Kopytin, D. Gaskiewicz, A. Bokiniec i J. Sobieraj oraz D. i M. Makowieccy.

L.L. Zalizniak zaprezentował koncepcję neolityzacji terenów Polesia rozważaną w rozległej geograficznie i genetycznie skali odniesień, obejmującej centra tego procesu nad Morzem Czarnym, w Kotlinie Karpackiej i na Niżu Środkowoeuropejskim. Komunikat na temat swoistości neolityzacji Polesia Prypeckiego przedstawił D. Gaskiewicz. Z kolei A.G. Kaleczyc podjęła zagadnienie neolityzacji większych przestrzennie obszarów, a mianowicie terenów współczesnej Białorusi. W swoim referacie ukazała ona szlaki dopływu w ów rejon nowych idei związanych z gospodarką wytwórczą oraz uwidoczniła długotrwałość chronologiczną i genetyczną złożoność procesu neolityzacji. Kwestie długotrwałości egzystencji i struktury powiązań kulturowych społeczeństw o ,mezolitycznym” stylu życia na Niżu Polskim (na przykładzie dwóch powierzchni próbnych: Kujaw i ziemi lubuskiej) omówili L. Czerniak i J. Kabaciński. W świetle ich argumentacji teza o długotrwałości rozwoju społeczności łowców i zbieraczy (do początków epoki brązu) jest bardziej prawdopodobna od obowiązującego obecnie w ujęciach podręcznikowych modelu stadialnego. A. Bokiniec i J. Sobieraj zaprezentowali wyniki badań obozowiska ze środkowej i młodszej epoki kamienia w Witowym Moście na Mazowszu, na którym udało się zaobserwować ciaggłość zasiedlenia przez społeczności o gospodarce przyswajającej od mezolitu aż po schyłkowy neolit i wczesną epokę brązu. Charakterystyki kulturowe: schyłkowego paleolitu wschodniej części Białorusi oraz mezolitu jej strefy zachodniej przedstawili W.F. Kopytin i W. Obuchowski. Referat D. i M. Makowieckich uzupełnił z kolei czysto archeologiczne rozważania poprzed- 
nich autorów o problematykę archeozoologiczną. Skoncentrowali się oni na charakterystyce rybołówstwa; ukazali jego wysoki poziom technologiczny i wagę kulturową dla społeczeństw, wśród których dominowały strategie przyswajające.

W sesji drugiej („Charakter i znaczenie kulturowe cech »wschodnich w dorzeczu Odry i Wisły w epoce neolitu «") znalazły się wystapienia Z. Sulgostowskiej, S. Kukawki, D. Prinke i M. Daszkiewicz oraz B. Józwiaka.

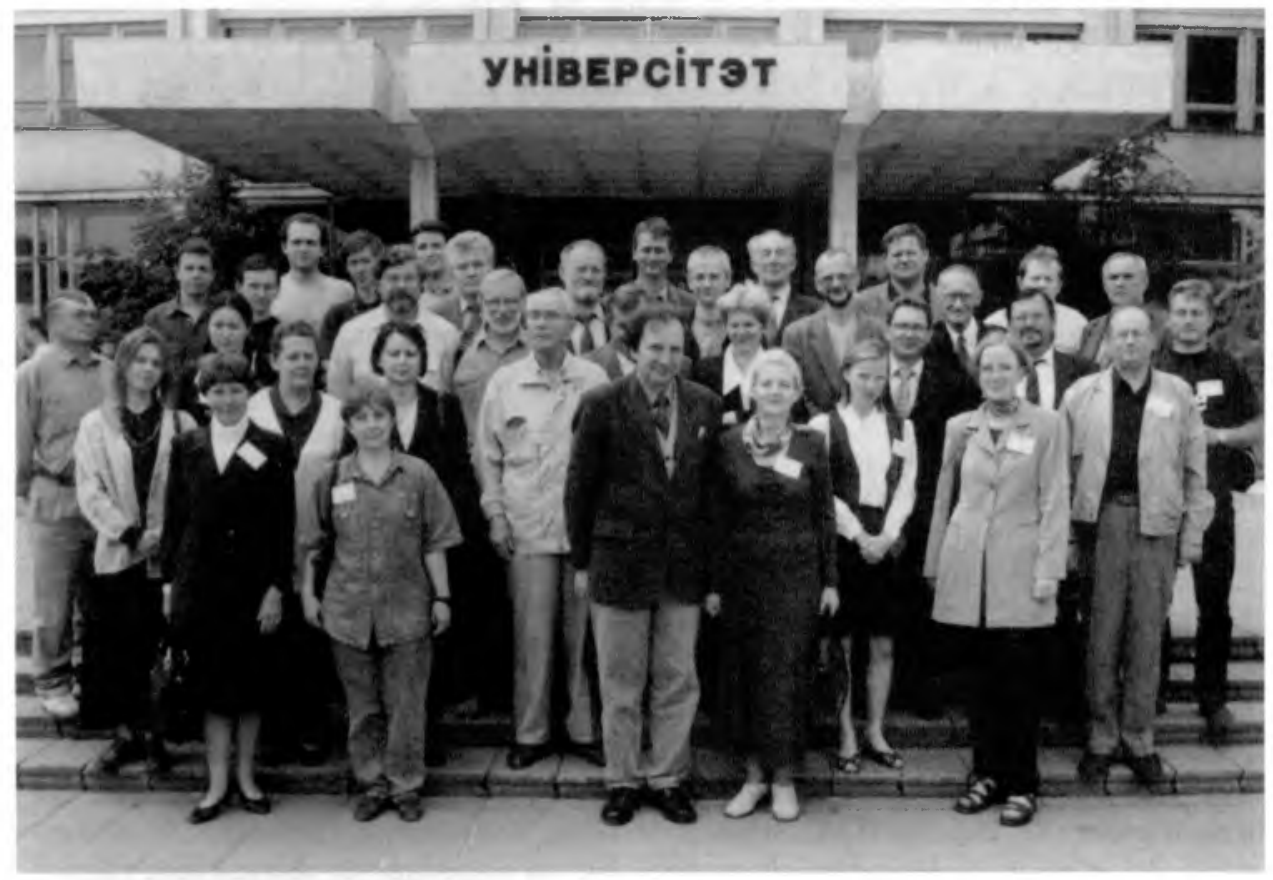

Uczestnicy międzynarodowego sympozjum „Od neolityzacji do początków epoki brązu. Przemiany kulturowe w międzyrzeczu Odry i Dniepru między VI i II tys. BC". Fot. J. Czebreszuk

Referat Z. Sulgustowskiej był systematyczną panoramą kontaktów kulturowych społeczeństw epoki kamienia na obszarze międzyrzecza Odry i górnego Dniepru. S. Kukawka skoncentrowal się z kolei na analizie roli społeczeństw „leśno-wschodnioeuropejskich" w tworzeniu się specyfiki aglomeracji kultury pucharów lejkowatych na ziemi chełmińskiej i czesściowo na Kujawach. Podobne zagadnienia, oparte m.in. na analizach mineralogicznych ceramiki, podjęły D. Prinke i M. Daszkiewicz. Ów dwugłos częściowo opozycyjnych względem siebie koncepcji, dotyczących tych samych zagadnień pradziejowych, był bardzo pozytywnym przykładem rzetelnej polemiki naukowej.

Sesja trzecia (,Charakter i znaczenie kulturowe cech »zachodnich « na wschód od dorzecza Wisły w epoce neolitu"), najbardziej obszerna, obejmowała wystapienia następujących referentów: D.J. Telegina z L.D. Potechina, W.I. Timofiejewa, W. Gumińskiego, R. Rimantienè, I. Loze, M. Szmyt, N.B. Burdo, M. Widejko, M.M. Czarniauskiego, L. Spicyny, E.P. Buna- 
tian, W.I. Kłoczko, A. Przybyl, W.F. Isajenko, O.P. Żurawlewa, G.A. Paszkiewicz z G.W. Ochrimienką oraz N.S. Kotowej z G.A. Paszkiewicz.

Otrzymaliśmy w niej wielowątkowy obraz recepcji cech neolitu środkowoeuropejskiego przez neolityczne społeczności Europy Wschodniej, od północnego krańca strefy leśnej (W.I. Timofiejew), poprzez tereny współczesnej Łotwy (l. Loze), Litwy (R. Rimantienè), Pojezierza Mazurskiego (W. Gumiński), Polesia Prypeckiego (W.F. Isajenko), dorzecza górnego Niemna (M.M. Czarniauski), aż po środkowe dorzecze Dniepru (E.P. Bunatian) i strefę lasostepu i stepu nadczarnomorskiego (N.B. Burdo, M. Widejko, W.I. Kłoczko, M. Szmyt). Obecność cech kultury pucharów lejkowatych (zwłaszcza referaty: W.I. Timofiejewa, W. Gumińskiego, M. Widejko i M.M. Czarniauskiego), kultury amfor kulistych (R. Rimantienė, M. Szmyt) czy kultury ceramiki sznurowej (I. Loze, E.P. Bunatian), kultury badeńskiej (A. Przybył) jest, w świetle bogatej faktografii zaprezentowanej w cytowanych pracach, bezsporna, a rola kulturowa niektórych $\mathrm{z}$ nich - kluczowa w wielu momentach pradziejów Europy Wschodniej (np. kultura pucharów lejkowatych dla kultury niemeńskiej - referat M.M. Czarniauskiego, czy wschodni ,exodus” kultury amfor kulistych - referat M. Szmyt). Tematykę gospodarczą, związaną z inspiracjami ,zachodnimi”, podjęli w swych wystapieniach G.A. Paszkiewicz i G.W. Ochrimienko (Polesie Prypeckie) oraz O.P. Żurawlew (środkowe Naddniestrze).

W sesji czwartej (,Kryteria wydzielenia, kierunki rozprzestrzeniania się i charakter kulturowy początków epoki brązu w międzyrzeczu Odry i Dniepru") swoje referaty przedstawili: A. Kośko, W.L. Lakiza, M.M. Krywalcewicz, J. Czebreszuk, E.M. Zajkowski, J. Dąbrowski, A. Bokiniec, P. Makarowicz, M.M. Czarniauski (junior), W.A. Cyrkunowa, P.W. Puczkow i O.P. Żurawlew, E. Laszkiewicz i A. Razłuckaja.

Omawiana sesja ukazała po raz pierwszy $w$ tak pełnej formie różnice w sposobie definiowania początków epoki brązu przez badaczy Niżu w strefie środkowo- i wschodnioeuropejskiej. Temu zagadnieniu szczególną uwagę poświęcił J. Dąbrowski. Dla badaczy z pierwszej z wzmiankowanych stref epoka brązu to nowy typ kultury, genetycznie związany z Kotliną Karpacką (J. Dąbrowski, A. Bokiniec) i Europą Zachodnią (J. Czebreszuk, P. Makarowicz), dla archeologów wschodnioeuropejskich jest nią pojawienie się nowych cech taksonomicznych, związanych konkretnie z tradycją kultury ceramiki sznurowej (W.L. Lakiza i M.M. Krywalcewicz). Prezentacja obu stanowisk wydaje się dobrym punktem wyjścia dla szerszej dyskusji, dotyczącej kryteriów kreowania w archeologii głównych cezur cywilizacyjnych.

Drugim wątkiem poruszonym w omawianej sesji była obecność w początkach epoki brązu (przełom IIl i II tys. przed Chr.) w międzyrzeczu Odry i Dniepru istotnych zbieżności kulturowych (J. Czebreszuk, P. Makarowicz) i szlaków powiązań interregionalnych (A. Kośko). Dwugłos na temat genezy kompleksu trzcinieckiego przedstawili w swych wystapieniach A. Bokiniec i P. Makarowicz. Zagadnienie metalurgii na Białorusi w epoce brązu podjęła W.A. Cyrkunowa, natomiast problemami gospodarczymi w neolicie i wczesnej epoce brązu na Białorusi zajęli się P.W. Puczkow z O.P. Żurawlewem (chów koni) oraz M.M. Czarniauski (broń z kości zwierzęcej), E. Laszkiewicz (ichtiofauna) i A. Rozłuckaja (chów zwierząt).

W trakcie sympozjum miała miejsce także sesja posterowa, w której badacze z wymienionych krajów przedstawili wyniki ostatnich badań nad problemami kulturowych inspiracji „Wschodu” na „Zachodzie” i „Zachodu” na „Wschodzie”. Na zakończenie obrad odbyła się generalna dyskusja nad najbardziej interesującymi poznawczo zagadnieniami prezentowanymi podczas poszczególnych sesji. 
Międzynarodowe sympozjum w Brześciu miało w opinii jego uczestników niewątpliwie prekursorski charakter. W gronie specjalistów, których doświadczenia naukowe wyrastały z dwóch różnych tradycji badawczych, omawiano zagadnienia powiązań i podobieństw kulturowych Wschodu i Zachodu - tych obu kluczowych dla Europy prowincji cywilizacyjnych. W świetle zebranych w różnych wystapieniach argumentów, w trakcie calej epoki kamienia i w początkach epoki brązu w międzyrzeczu Odry i Dniepru trwał ustawiczny proces wymiany informacji kulturowej. Było to więc sąsiedztwo bogate we wzajemne kontakty, co jednak nie znalazło, jak dotąd, odzwierciedlenia w ujęciach syntetyzujących i podręcznikowych. Niewątpliwie więc przygotowane do druku materiały sympozjalne stworzą solidną bazę do rewizji dotychczasowych modeli. Ich publikacja jest bardzo potrzebna, gdyż znajdzie ona niewątpliwie szeroki krąg odbiorców we wszystkich krajach Europy Środkowej i Wschodniej, obejmujący nie tylko archeologów, ale też historyków, językoznawców i etnologów.

Trudno przecenić znaczenie sympozjum brzeskiego dla prahistorii Europy ŚrodkowoWschodniej. Było ono propozycją znalezienia formuły porozumienia między środowiskami naukowymi zajmującymi się - często z różnej perspektywy badawczej - tymi samymi lub podobnymi problemami. W toku dyskusji, często bardzo polemicznej, zarysowano nowe, nieobecne do tej pory $w$ literaturze fachowej, przestrzenie poznawcze, zadano nowe pytania, wytyczono kierunki badań złożonego problemu interakcji wspólnot pogranicza Wschodu i Zachodu. Sympozjum udowodniło też, iż w wymianie idei naukowych nie powinno być (i nie może być) jakichkolwiek barier (organizatorzy celowo wybrali Brześć - miasto pogranicza - jako najbardziej odpowiednie miejsce na sympozjum). Trzeba mieć nadzieję, że podobne inicjatywy w przyszłości zintegrują różne środowiska naukowe naszego regionu i zapobiegna groźbie powstania, w bliskiej perspektywie, nowej rubieży cywilizacyjnej wzdłuź wschodniej granicy Rzeczypospolitej.

Janusz Czebreszuk, Przemystaw Makarowicz

\section{ARCHEOLOGIA MIĘDZY WSCHODEM A ZACHODEM. TEORIA I PRAKTYKA W PRZEKROJU EUROPEJSKIM (SPRA WOZDANIE Z MIĘDZYNARODOWEJ KONFERENCJI ARCHEOLOGICZ- NEJ, KTÓRA ODBYLA SIĘ W POZNANIU, W DNIACH 18-21 MAJA 2000 R.)}

Konferencja „Archaeologies East - Archaeologies West. Connecting Theory and Practice Across Europe" została zorganizowana przez Instytut Prahistorii Uniwersytetu im. Adama Mickiewicza w Poznaniu, Poznańskie Towarzystwo Archeologiczne, Instytut Archeologii i Etnologii PAN w Krakowie, Brandenburgisches Landesamt für Denkmalpflege und Archäologisches Landesmuseum w Wünsdorf, Deutsches Archäologisches Institut w Berlinie oraz Theorie-AG Deutschland w Berlinie. Metaforę konferencji stanowił most - swoiste przesłanie dla współczesnej archeologii, zwłaszcza europejskiej.

W komitecie naukowym konferencji znaleźli się przedstawiciele głównych ośrodków archeologii polskiej (B. Gediga - Wrocław, A. Kośko - Poznań, J. Kruk - Kraków, J. Machnik - Kraków, D. Minta-Tworzowska - Poznań, R. Schild - Warszawa) i niemieckiej (F. Berte- 